\title{
Drip irrigation can effectively apply boron to San Joaquin Valley vineyards
}

\author{
William L. Peacock \\ L. Peter Christensen
}

$\nabla$

\section{Boron deficiency of grapevines} occurs occasionally on the east side of the San Joaquin Valley. Its symptoms include shot berries, shoot-tip dieback and leaves with yellowish mottling between veins. Boron must be applied carefully because the range between deficiency and toxicity is narrow. Our research evaluated the safety and efficacy of boron fertigation of grapevines using drip irrigation. Applying boron annually at $1 / 3$ pound per acre to a moderately deficient vineyard elevated tissue levels into the adequate range within 2 years. However, the amount of boron used in a fertigation maintenance program will vary with leaching potential. Blade samples should be routinely monitored following fertigation and fertilizer amounts adjusted accordingly to avoid boron toxicity or deficiency.

W hile San Joaquin Valley vineyards are currently fertilized with boron through the soil and foliage (Christensen 1986), some growers have expressed interest in applying boron via drip irrigation or "fertigation." Fertigation is a relatively simple, cost-effective and efficient way to apply nutrients. However, irrigation water with more than 1 part per million (ppm) boron can lead to vine toxicity, so the safety of boron fertigation is also a concern. Our research evaluates the safety and efficacy of boron fertigation in grapevines using drip irrigation.

Boron is unique among the micronutrients due to the narrow range between deficiency and toxicity in soil and plant tissues. For grapevines, this range is $0.15 \mathrm{ppm}$ to $1 \mathrm{ppm}$ in saturated soil extracts, and $30 \mathrm{ppm}$ to $80 \mathrm{ppm}$ in leaf tissue. The goal of boron fertilization

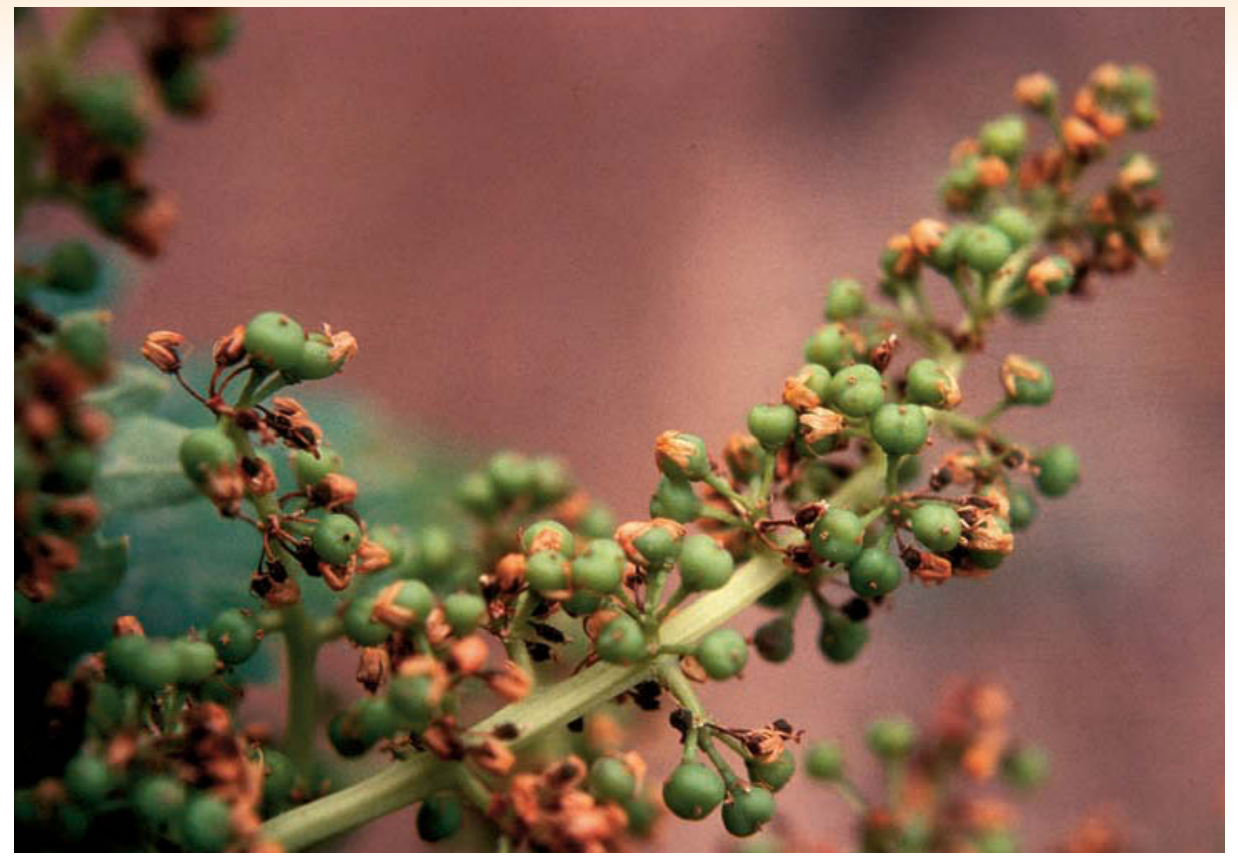

of grapevines is to keep tissue levels within this narrow range, since both deficiency and toxicity can have serious negative effects on vine growth and production. Fertilization amounts must be precise to avoid toxicity while providing adequate boron to satisfy grapevine requirements (Christensen et al. 1978; Christensen and Peacock 1998).

On the east side of the San Joaquin Valley, boron deficiency of grapevines occurs on soils formed from igneous rocks of the Sierra Nevada. This parent material is low in total boron, which is crystallized in borosilicate minerals that are highly resistant to weathering. Boron deficiency is often associated with sandy soils and vineyard areas with excessive leaching, such as in low spots or near leaky irrigation valves. Vine symptoms of boron deficiency are more widespread and pronounced following high rainfall years, when greater amounts of soluble boron are leached from the root zone. In addition, snowmelt water has very low levels of boron, and vineyards irrigated primarily with this water have a greater risk of deficiency.

Boron is required for the germination and growth of pollen during flowering, and vines that are deficient

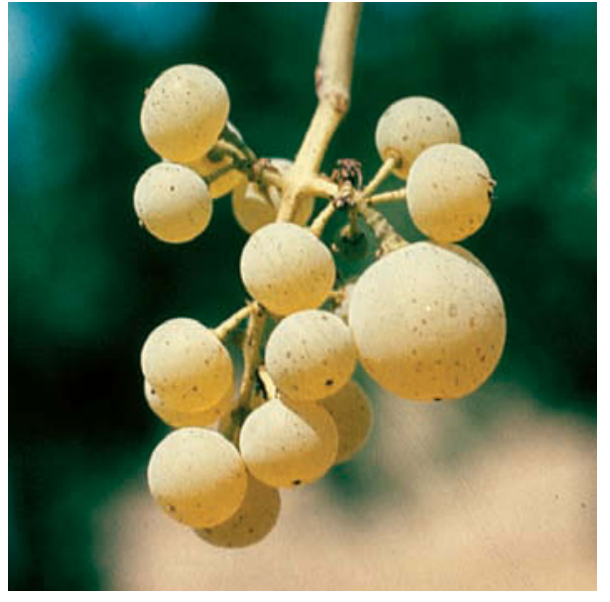

in this micronutrient will have clusters that set numerous shot berries, small berries with a distinctive pumpkin shape. When boron deficiency is severe, vines produce almost no crop. Foliar symptoms appear in the spring: shoots have shortened, swollen internodes and their tips sometimes die, and leaves have irregular, yellowish mottling between the veins.

Grapevines are also sensitive to too much boron. Toxicity is common on the west side of the San Joaquin Valley, where most soils are derived from marine sedimentary and metasedimentary parent material that is rich in easily 
The goal of boron fertilization of grapevines is to keep tissue levels within a narrow range, since both deficiency and toxicity can have serious negative effects on vine growth and production.

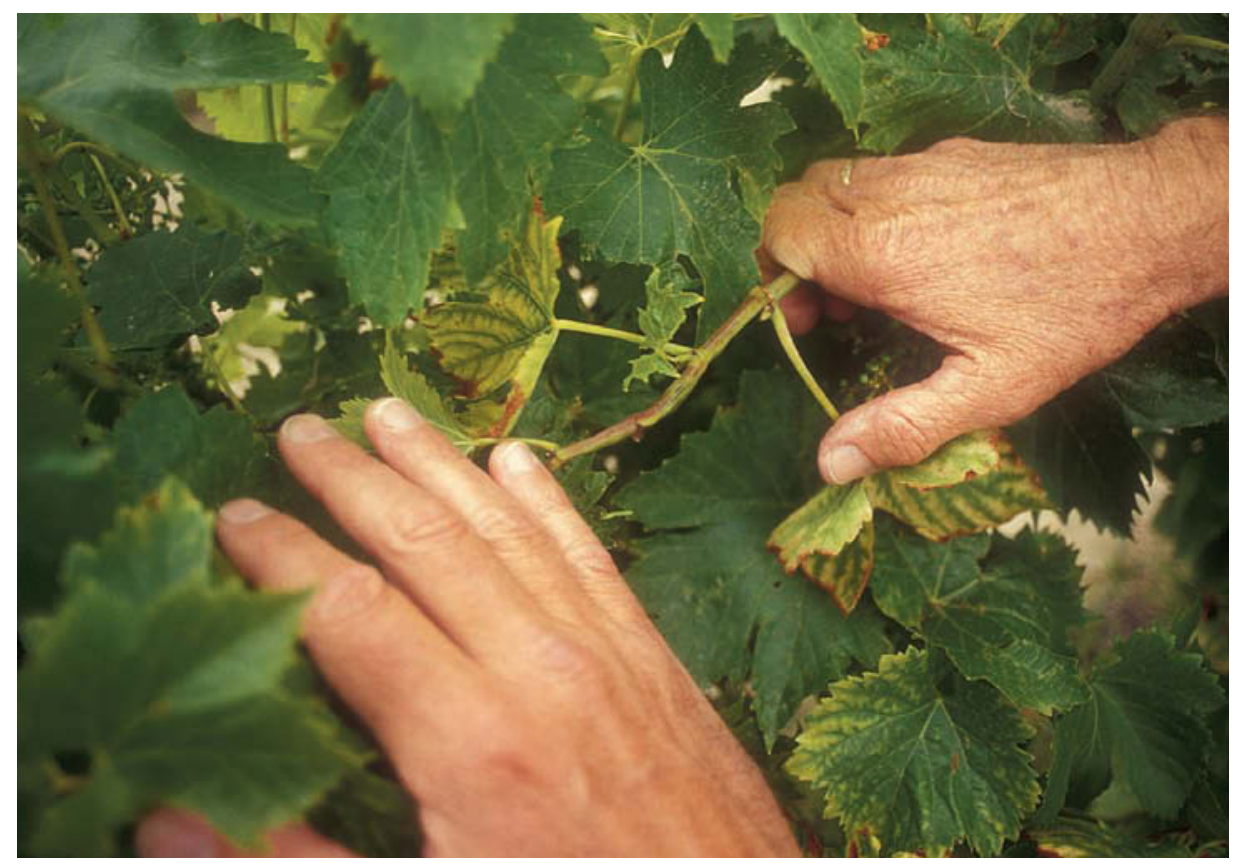

Boron-deficient vines have, facing page, bottom, clusters that set numerous shot berries, small berries with a distinctive pumpkin shape; or, facing page, top, calyptras that stick on young, developing berries. Above, shoots have shortened and swollen internodes, and shoot tips sometimes die.

weathered boron minerals. Symptoms of boron toxicity include leaves that are cupped downward in the spring and that develop brown spots adjacent to the leaf margin in middle or late summer, intensifying and leading to necrosis as boron accumulates. Yields are reduced, the result of diminished vine vigor and canopy development. When foliar boron sprays are applied in excess in the spring, juvenile leaves become cupped within 2 weeks; however, vines quickly recover and yields are usually unaffected.

Toxicity also occurs when boron fertilizer is applied in excess, regardless of the soil type, and this can lead to yield loss. Over-fertilization is the sole reason for boron toxicity on the east side of the San Joaquin Valley, so it is critical to establish how much boron fertilizer can be applied safely and effectively. Our research investigated the uptake of boron by grapevines when fertilizer was applied with a drip-irrigation system.

\section{Measuring boron in grapevines}

Research was conducted from 1998 to 2001 in a mature 'Thompson Seedless' raisin vineyard near Woodlake in Tulare County. The vineyard was planted in Cajon sandy loam on a recent alluvial fan associated with the Kaweah River. This soil is derived from granitic parent materials, and the surface soil is highly micaceous with a slight to moderate amount of lime. The underlying soil ( 2 to 3 feet deep) has a coarse, sandy texture.

At the onset of this study, the vineyard's boron status was in the questionable range for deficiency. The vine's leaf petioles and blades contained about 30 ppm boron. While the foliage had no symptoms of boron deficiency, in the past the grower had observed sticking caps and pumpkin-shaped shot berries, which are indicative of boron deficiency. During the course of the research, the vineyard was drip-irrigated from April through October. The vineyard canopy covered $60 \%$ of the land surface during summer months and about 20 inches of water was applied during the season.

Boron treatments consisted of applying fertilizer in varying amounts 3 weeks prior to bloom on May 18, 1998, and
TABLE 1. Actual pounds of boron applied* per acre over 2-year treatment period, 1998 and 1999

\begin{tabular}{lccc}
\hline Treatment & 1998 & 1999 & Total \\
\hline \multicolumn{4}{c}{$\ldots \ldots \ldots$} \\
1 & 0 & 0 & 0 \\
2 & $1 / 3$ & $1 / 3$ & $2 / 3$ \\
3 & $2 / 3$ & $2 / 3$ & $11 / 3$ \\
4 & 1 & 1 & 2 \\
5 & $1 / 6$ & $2 \dagger$ & $21 / 6$ \\
\hline * To determine the pounds of Solubor applied, multiply \\
the actual boron rate by 4.9. \\
+ The 2-pound rate was applied to evaluate potential \\
toxicity.
\end{tabular}

then again 3 weeks prior to bloom the following year, on May 3, 1999. Growers who fertigate grapevines with a drip system generally inject material into the irrigation water over a 45-to60-minute period at the beginning of an irrigation set. We simulated fertigation by applying Solubor, a soluble boron product (20.5\% boron), to a shovel-sized hole beneath drippers during the first hour of the irrigation set. By doing this, precise amounts of boron could be applied to each plot (the issue of dripper emission uniformity was eliminated) and plot size could be reduced. This technique has been used successfully in previous research with other nutrients (Christensen et al. 1991; Peacock et al. 1991). The experiment was designed as a randomized complete block with five treatments, five blocks and five vine plots (table 1).

To evaluate the rate of boron uptake and accumulation in tissue with consecutive years of fertilization, grape tissue samples were collected in 1998 and 1999 at bloom and then again about 6 weeks later during veraison. Veraison is the stage of development where berries begin to soften and/or color. To evaluate carryover, leaf tissue samples were also collected at this Tulare County site at both bloom and veraison in 2001, 2 years after the fertilization was discontinued. In each case, 100 petioles and 50 blades were sampled per plot from the center three vines. Petioles and blades were taken opposite inflorescences during bloom, and recently matured leaves were sampled at veraison. Samples were oven-dried, ground in a Wiley mill and sent to the UC Davis DANR Analytical Laboratory for analysis of total boron. Statistical analysis was by ANOVA using least 
TABLE 2. Blade levels at bloom and veraison, following boron fertigation applied 3 weeks prior to bloom in 1998

\begin{tabular}{|c|c|c|c|c|}
\hline \multirow[b]{2}{*}{ Treatment } & \multicolumn{2}{|c|}{$\begin{array}{l}\text { Cajon sandy loam } \\
\text { (Tulare Co.) }\end{array}$} & \multicolumn{2}{|c|}{$\begin{array}{l}\text { Pollaski sandy loam } \\
\text { (Fresno Co.) }\end{array}$} \\
\hline & Bloom & Veraison & Bloom & Veraison \\
\hline actual boron, Ib/acre & \multicolumn{4}{|c|}{$\ldots \ldots \ldots \ldots \ldots p p m$} \\
\hline Unfertilized control & $31 a *$ & $32 a$ & $40 a$ & $48 a$ \\
\hline $1 / 3$ & $33 a b$ & $40 \mathrm{ab}$ & $48 a b$ & $53 a$ \\
\hline $2 / 3$ & $38 b$ & $43 b c$ & $54 b$ & $60 a b$ \\
\hline 1 & $39 b$ & $49 c$ & $58 b$ & $70 b$ \\
\hline $1 / 6$ & $31 a$ & $38 a b$ & - & \\
\hline
\end{tabular}

TABLE 3. Boron in leaf tissue after 2 consecutive years of fertigation, Tulare County vineyard

\begin{tabular}{|c|c|c|c|c|}
\hline \multirow[b]{2}{*}{ Treatment } & \multicolumn{2}{|c|}{ Bloom } & \multicolumn{2}{|c|}{ Veraison } \\
\hline & Petiole & Blade & Petiole & Blade \\
\hline actual boron, Ib/acre & & & $n \ldots$ & $\cdots \cdots$ \\
\hline Unfertilized control & $29 a^{*}$ & $36 a$ & $31 a$ & $35 a$ \\
\hline 2/3 lb. (1/3 lb. each year) & $32 b$ & $46 a b$ & $36 b$ & $45 b$ \\
\hline $11 / 3 \mathrm{lb}$. (2/3 lb. each year) & $34 b$ & $53 b c$ & $38 b$ & $54 c$ \\
\hline $2 \mathrm{lb}$. (1 lb. each year) & $37 c$ & $62 c$ & $41 c$ & $61 \mathrm{~cd}$ \\
\hline $21 / 6 \mathrm{lb}$. (1/6 lb. then $2 \mathrm{lb}$.) & $39 c$ & $59 c$ & $41 c$ & $68 d$ \\
\hline
\end{tabular}

significance difference to separate treatment means.

A second experiment was conducted in 1998 in Fresno County near Selma, in a mature Thompson Seedless raisin vineyard planted on Pollaski sandy loam and drip-irrigated. The soil was formed in place from the weathering of softly to moderately consolidated granitic sediments. The particle size distribution of the surface soil is $63 \%$ sand, $25 \%$ silt and $12 \%$ clay. At the onset of the experiment, boron tissue levels were in the adequate range, $40 \mathrm{ppm}$.

In both experiments, drip irrigations during the season were based on a schedule using historical evapotranspiration and developed for raisin vineyards in the San Joaquin Valley (Peacock et al. 1987; Peacock et al. 1998). The irrigation source was high-quality pump water with a boron concentration less than $0.1 \mathrm{ppm}$. The experimental design and methods were identical in both vineyards, except that the $1 / 16$-poundper-acre boron treatment was omitted in the second (Fresno County) vineyard. The Fresno County trial was discontinued after tissue samples were taken at bloom and veraison in 1998.

\section{Boron uptake}

At both the Tulare and Fresno county sites, boron uptake was rapid when fertilizer was applied in the spring. In both vineyards, applying boron at $2 / 3$ or 1 pound per acre increased the boron concentration in blades by bloom, 3 weeks after application. Boron increased further in blades by veraison (table 2). In the Tulare County vineyard, boron in bloom tissue increased from a questionable deficiency range to adequate; at the Fresno location, boron in bloom tissue increased from $40 \mathrm{ppm}$ to 54 ppm, a dramatic increase considering boron fertilizer was applied just 3 weeks prior. This indicates that boron uptake is rapid. None of the fertigation treatments resulted in either symptoms of boron toxicity or deficiency. Applying boron at $1 / 3$ pound per acre or less did not significantly increase boron tissue levels by bloom or veraison at either site the first year.

Fertigation over consecutive years was evaluated at the Tulare County location. Boron in grapevine tissue continued to increase with consecutive years of application. At the higher fertilizer rate ( 1 pound boron per acre), boron levels in blades increased from 35 $\mathrm{ppm}$ in control vines to about $60 \mathrm{ppm}$. We speculate that continuing with annual applications of 1 pound boron per acre would result in toxicity within 4 to
5 years. The $1 / 3$-pound-per-acre rate significantly elevated boron in blades by veraison of the second year to adequate levels (table 3). There were no visual signs of toxicity in any of the fertilizer treatments, even when boron was applied at 2 pounds ( 9.8 pounds Solubor) per acre in a single application.

Boron levels in tissue remained unchanged 2 years after fertilization was discontinued at the Tulare County location (fig. 1). This indicates substantial treatment longevity with fertigation of a drip-irrigated vineyard. Rainfall during this experiment was below normal, which helped minimize leaching. Also, well-managed drip irrigation minimizes leaching. Under drip irrigation, salts tend to accumulate near the soil surface and 2 to 3 feet away from the drip line, with minimal water and salt movement below the root zone when irrigations are accurately scheduled (Peacock 2004).

Boron concentrated more in the blades than in the petioles in response to fertilization. At the onset of the Tulare County experiment, boron concentrations in petioles and blades were similar at $31 \mathrm{ppm}$ and $34 \mathrm{ppm}$, respectively. Fertilizing with 1 pound boron per acre for 2 consecutive years resulted in a $25 \%$ increase of boron in petioles but a $76 \%$ increase in blades (fig. 2). All

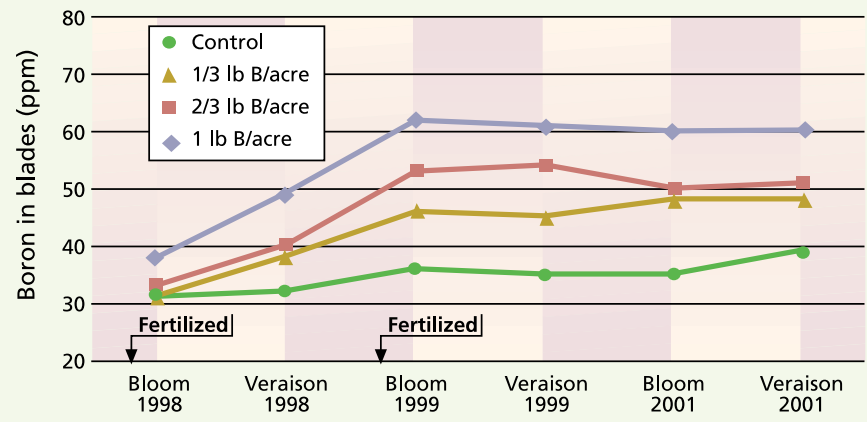

Fig. 1. Boron in blades is sustained 2 years after fertigation, indicating excellent carryover with drip irrigation.

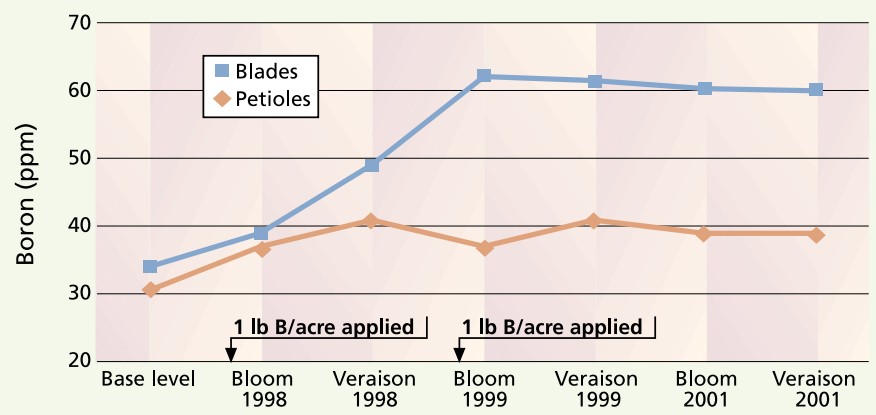

Fig. 2. Boron accumulated more in blades than in petioles following fertigation. 
fertilizer treatments increased boron in blades more than in petioles, indicating that blades should be sampled when monitoring the vines' boron status following fertilization. Potential boron toxicity values at the time of sampling during the bloom period are $80 \mathrm{ppm}$ for petioles and 120 ppm for blades, and in mid- to late summer are 100 ppm for petioles and 300 ppm for blades.

\section{Leaching and treatment longevity}

Annual boron fertigation at $1 / 3$ pound per acre elevated grapevine tissue levels from questionable to the adequate range within 2 years (Tulare County location). In addition, tissue boron levels remained unchanged 2 years after fertilization was discontinued. This is probably because leaching was reduced by two factors: below-normal rainfall and accurately scheduled drip irrigations. After fertilization, boron was concentrated more in blades than in petioles, indicating that blades are the best choice for monitoring toxicity. Blade samples should be monitored on a routine basis and fertilizer amounts should be adjusted accordingly to avoid boron toxicity or deficiency.

The results of this research can be applied to other drip-irrigated vineyards in the San Joaquin Valley under similar conditions: rapidly drained soils, highquality irrigation water, and low boron content in soil, water and vine tissue. In other regions of the state where winter rainfall is much higher, there would presumably be more leaching of boron fertilizer during winter months and less carryover time after fertilization is discontinued. In contrast, less leaching and greater carryover of boron would be expected in areas of less rainfall or on soils with finer texture and higher water-holding capacity. The amount of boron fertigation used in a maintenance program will vary with leaching potential. These variables underscore the importance of monitoring boron in tissue when developing a long-term fertilization program.

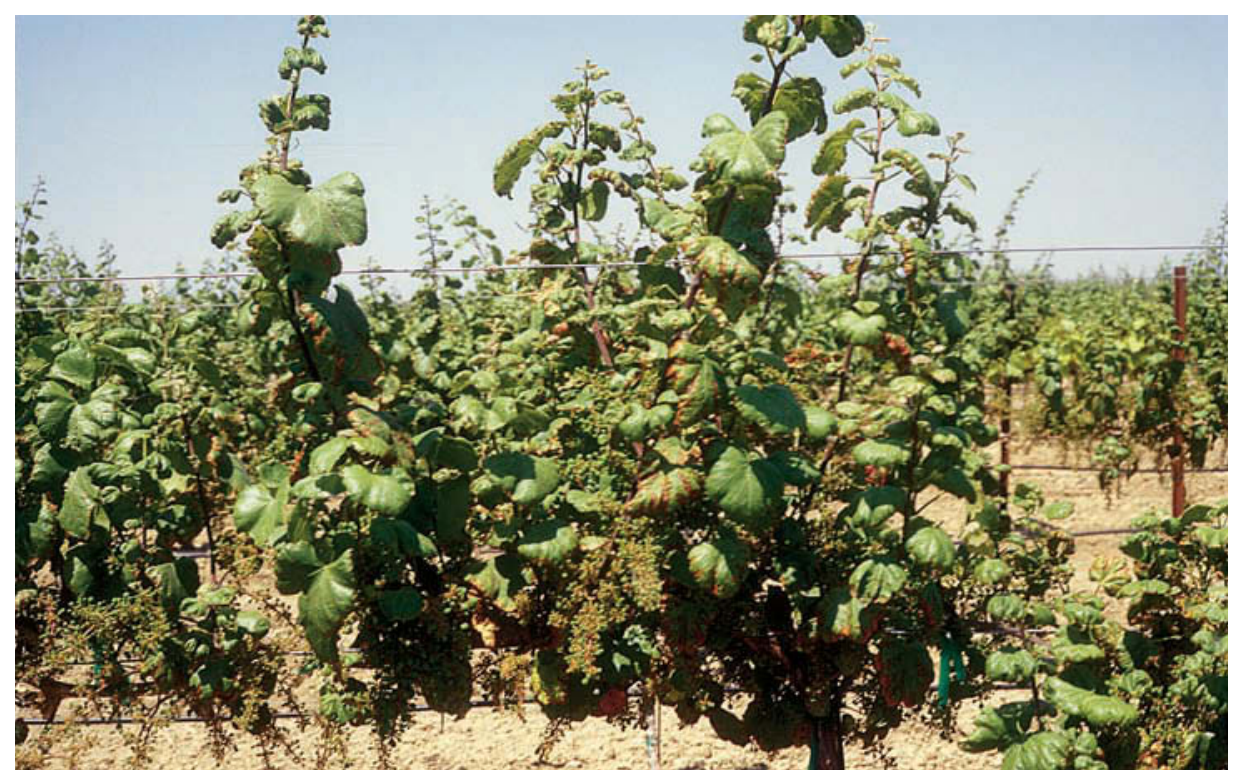

Symptoms of boron toxicity include leaves that are cupped downward with necrotic margins on mature leaves.

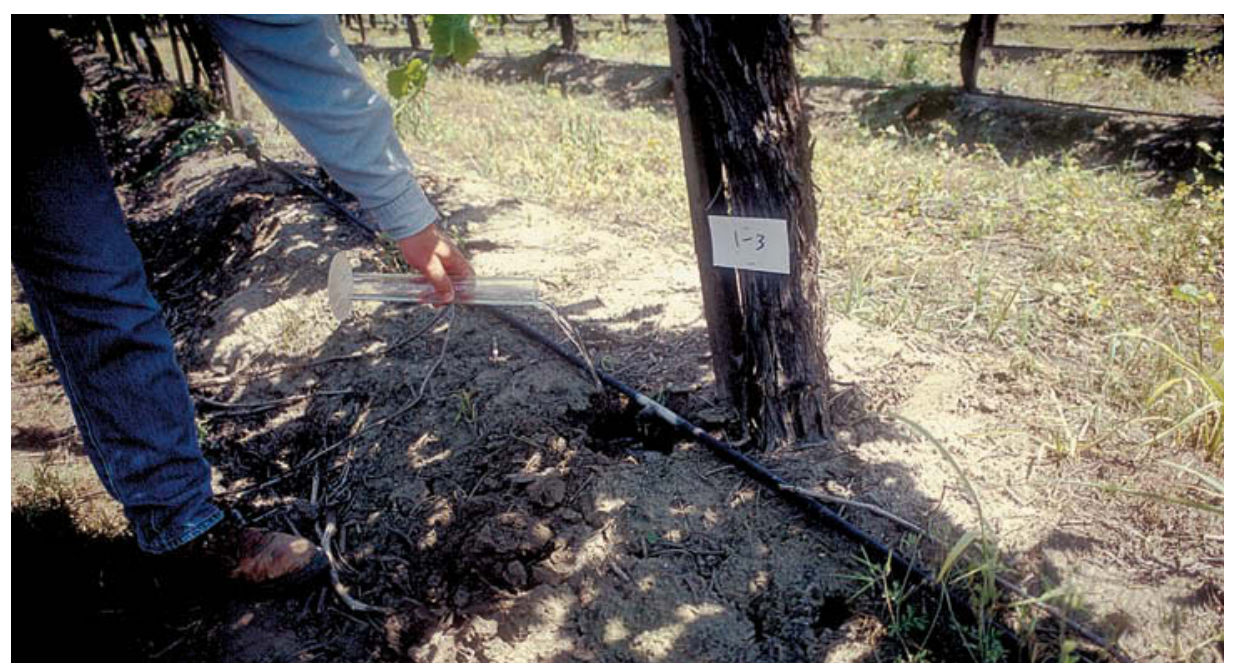

Solubor, a soluble boron product ( $20.5 \%$ boron), was applied to an excavation beneath drippers to simulate fertigation at varying amounts and timing.

W.L. Peacock is Farm Advisor, UC Cooperative Extension (UCCE), Tulare County; and L.P. Christensen is UCCE Viticulture Specialist Emeritus, Department of Viticulture and Enology, UC Davis.

\section{References}

Christensen P. 1986. Boron application in vineyards. Cal Ag 40(3-4):17-8.

Christensen LP, Kasimatis AN, Jensen FL. 1978. Boron. In: Grapevine Nutrition and Fertilization. ANR Pub 4087, Oakland, CA. p 25-7, 37.

Christensen LP, Peacock WL. 1998. Mineral nutrition and fertilization. In: Christensen LP (ed.). Raisin Production Manual. ANR Pub 3393, Oakland, CA. p 112-3.

Christensen LP, Peacock WL, Bianchi ML.
1991. Potassium fertilization of grapevines using drip irrigation. Am J Enol Vitic 42:227-32.

Peacock WL. 2004. Fertigating drip irrigated vineyards with macro- and micronutrients. In: Christensen LP, Smart DR (eds.). Proc Soil Environment and Vine Mineral Nutrition Symp. Am J Enol Vitic. p 129-33.

Peacock WL, Christensen LP, Andris HL. ule for average-canopy vineyards in the San Joaquin Valley. Am J Enol Vitic 38:113-9.

Peacock WL, Christensen LP, Hirschfelt DJ, et al. 1991. Efficient uptake and utilization of nitrogen in drip- and furrow-irrigated vineyards. In: Rantz (ed.). Proc Int Symp on Nitrogen in Grapes and Wine. Am J Enol Vitic. p 116-9.

Peacock WL, Williams LE, Christensen LP. 1998. Water management and irrigation scheduling. In: Christensen LP (ed.). Raisin Production Manual. ANR Pub 3393, Oakland, CA. p 127-33. 1987. Development of a drip irrigation sched- 